\title{
Task-Based Language Teaching and Implementing Consciousness-Raising Tasks
}

\author{
Maryam Abdollahzadeh* \\ Ph.D. Candidate in TEFL, Islamic Azad University of Maibod, Iran
}

*Corresponding Author: Maryam Abdollahzadeh, Ph.D. Candidate in TEFL, Islamic Azad University of Maibod, Iran

\begin{abstract}
Communicative Language Teaching emphasizes developing learners' communicative ability. One of the subdivisions of this approach is Task-Based Language Teaching which refers to the use of tasks as the main unit of instruction in language teaching. Task-Based Language Teaching aims at considering the specific needs of particular learners. Consciousness-raising tasks also could be an alternative to traditional grammar teaching in which memorization of specific rules and rule articulation through decontextualized instruction was practiced. By using carefully designed activities and tasks, learners develop explicit knowledge of grammatical aspects which can facilitate the implicit knowledge and the ability to successfully and effectively communicate. Language teachers can use consciousness-raising tasks for pedagogical purposes in their classes whenever they suppose it can be of more privilege. In the present study, Task-Based Language Teaching and implementing consciousness-raising tacks are going to be critically reviewed.
\end{abstract}

Keywords: Task-Based Language Teaching, Consciousness-Raising Tasks, EFL Learners, Learners' Needs, Communicative Ability

\section{TASK-BASED LANGUAGE TEACHING}

Communicative language teaching approach has spread in the 1980's and its emphasis was on developing learners' communicative ability. The result of this development was the emergence of task-based language teaching which can be called TBLT. There are various interpretations of TBLT. Three characteristics of this approach are mentioned in this part; the first one is that TBLT is in line with a learner-centered educational philosophy (Ellis, 2003; Nunan, 2005; Richards \& Rodgers, 2001); the second is that it includes certain components such as goal, procedure, and specific outcome (Murphy, 2003; Nunan, 2004; Skehan, 1998); and the third characteristic is that it supports contentoriented meaningful activities rather than linguistic forms (Beglar \& Hunt, 2002; Carless, 2002; Littlewood, 2004).

According to Richards and Rodgers (2014), TBLT mentions the notion of task as a central unit of planning and teaching. A task is generally defined as an activity that is carried out using language, such as finding a solution to a puzzle, reading a map, making a telephone call, writing a letter, and assembling a toy. The tasks have been defined from a variety of perspectives. Nunan (1989) defines a communicative pedagogical task as "a piece of classroom work which involves learners in comprehending, manipulating, producing or interacting in the target language while their attention is principally focused on meaning rather than form" (p.10). Long (1985) provides a broad definition of task as follows:

A task is a piece of work undertaken for oneself or for others, freely or for some reward. Thus, examples of tasks include painting a fence, dressing a child, filling out a form, buying a pair of shoes, making an airline reservation, borrowing a library book, etc. In other words, by "task" is meant the hundred and one things people do in everyday life, at work, at play and in between. (p. 89)

Tasks have four major functions: 1. orientation functions: processes for generating and distributing information necessary to task accomplishment to team members, 2. organizational functions: processes necessary for members to coordinate actions necessary for task performance, 3. adaptation functions: processes occurring as team members adapt their performance to each other to complete the 
task, and 4, motivational functions: defining team objectives and energizing the group to complete the task (Richards \& Rodgers, 2003). Richards, Platt, and Weber (1986) define tasks as "an activity or action which is carried out as the result of processing or understanding the language" (p.289).

Nunan (1989) drew a distinction between real-world tasks or target tasks and pedagogical tasks. He states that real world tasks are those which are found to be important in a needs analysis and turn out to be important and useful in the real world. The pedagogic tasks do not necessarily reflect real-world tasks.

Tasks can be divided into 'unfocused' or 'focused'. Unfocused tasks are tasks designed to provide learners with opportunities for using language in general communicatively. Focused tasks are tasks designed to provide opportunities for communicating using some specific linguistic feature (Ellis, 2009).

It is also worth mentioning that the constructivist theory of language leaning as well as CLT support the tenets of task-based language learning reacting to the constraints exerted by the traditional PPP approach that is procedure, presentation and practice (Ellis, 2003; Long \& Crooks, 1991). Task-based language teaching can be seen as the strong version of CLT recommending language use as the main purpose of language learning. Therefore, the syllabus specifications are based on communicative tasks and not on grammatical structures. Learning in TBLT is believed to be a developmental process which stimulates communication and interaction (Breen, 1987; Candlin \& Murphy, 1987; Nunan, 1989; Prabhu, 1987). Hover (1986) suggested letters, newspaper extracts, memo notes, shopping lists, recipe etc. as some of the authentic sources to choose from.

TBLT is motivated primarily by a theory of learning rather than a theory of language. However, several assumptions about the nature of language can be said to underlie current approaches to TBLT. 1. Language is primarily a means of making meaning. Meaning has a central role in language use. 2 . Multiple models of language inform TBI. It is linked to all three models of language theory, i.e. structural, functional, and interactional. 3. Lexical units are central in language use and language learning. Vocabulary is here used to include lexical phrases, sentence stems, prefabricated routines, and collocations. 4. Conversation is the central focus of language and the keystone of language acquisition.

Based on Richards and Rodgers' (2001) idea, learners have a number of roles such as: 1. Group participant: Many tasks will be done in pairs or small groups. 2. Monitor: Classroom activities should be designed so that students have the opportunity to notice how language is used in communication. 3 . Risk-taker and innovator: Many tasks will require learners to create and interpret messages for which they lack full linguistic resources and prior experience. The skills of guessing from linguistic and contextual clues, asking for clarification, and consulting with other learners may also need to be developed. Teachers have the following roles: 1. selecting and sequencing tasks, 2. preparing learners for tasks, and 3. consciousness-raising. According to Nunan (1989), role reflects what language learners and the teacher are expected to do in performing the tasks. Richard and Rodgers (1986) assert that the learners' roles are deeply related to what the teacher status and function is. Breen and Candlin (1980) deemed three major roles for the language teacher: a. facilitator, b. participant, c. observer and learner.

\section{CRITICISM ON TBLT}

TBLT has also been subjected to criticism on the basis of empirical studies of its implementation in different instructional settings. In particular, questions have been raised by Li (1998), Carless (2004), and Butler (2005), among others, as to whether TBLT is practical in Asian countries, where teachers are likely to adhere to a philosophy of teaching that is radically different to that underlying TBLT, and where they also face practical problems such as limited second language proficiency and the washback from tests they need to prepare their students for. The definition of a task has proved problematic. This is evident in the discussion of various definitions to be found in Bygate, Skehan, and Swain (1991), Ellis (2003). Another criticism that Widdowson (2003) makes of TBLT is that tasks prioritize pragmatic meaning and neglect semantic meaning. The former refers to the way language is used in natural contexts of use; the latter refers to the notional meanings encoded in the lexis and grammar of a language. A common objection to TBLT is that learners' performance of tasks will result only in samples of impoverished language use that are of little acquisitional value. Task- 
based syllabus affords inadequate coverage of grammar. Sheen (2003) claims that in task-based language teaching there is 'no grammar syllabus', and went on to argue that proponents of TBLT generally offer little more than a brief list of suggestions regarding the selection and presentation of new language. According to Swan (2005), task-based language teaching promotes learnercenteredness at the expense of teacher-directed instruction. Swan comments that the thrust of TBLT is to cast the teacher in the role of manager and facilitator of communicative activity rather than an important source of new language.

Some of the criticisms on TBLT have lack of merit; however, the more principled ones can be considered by the scholars and practitioners to have a better and more effective teaching.

\section{CONSCIOUSNESS-RAISING TASKS}

It seems to be generally accepted that in order to be able to successfully communicate, one needs both linguistic competence, which is the grammatical structure of language, and also communicative competence, which are the rules of real communication. Therefore, the importance of grammatical knowledge in language teaching is obvious, for one cannot develop his/her language use with limited grammar knowledge. One of the important aspects of teaching grammar is finding a sound approach to effectively teach it, since there is no best method of teaching grammar and only through research we can find out the effectiveness of different techniques which are proposed by methodologists (Richards \& Renandya, 2002).

Ellis (2002) describes consciousness-raising as an approach toward grammar teaching and claims that "consciousness-raising ... involves an attempt to equip the learner with an understanding of a specific grammatical feature - to develop declarative rather that procedural knowledge of it" (p. 168). Rutherford also explains that consciousness-raising "is the means to an end, not the end itself". He further asserts that "whenever sentences have to be produced, what is raised to consciousness is not the grammatical product but aspects of the grammatical process" (as cited in Kumaravadivelu, 2006, p. 58). Kumaravadivelu himself defines consciousness-raising task as "it refers to the deliberate attempt to draw the learners' attention to the formal processes of their L2 in order to increase the degree of explicitness required to promote L2 development" (p. 59).

Ellis (2002) similarly states that the main purpose of consciousness-raising is to develop explicit knowledge of grammar which is an intellectual knowledge that can be gathered about any subject. It helps learners to know about the linguistic features, talk about and discuss them, not to know how to perform them correctly, thus it has a delayed rather than instant effect on learners production.

To make this clear we should mention the difference between explicit and implicit knowledge as well as their relationship. According to Fotos (1993), we have two general types of knowledge: the first type is declarative or explicit knowledge which is the knowledge about something. It is conscious factual information. And the second type is procedural or implicit knowledge which is the knowledge of how to do something, which is usually unconscious and is used automatically. Fotos further mentions that recent research suggests that these two language knowledge systems are in fact connected through noticing and awareness, a connection which has referred to as "Noticing Hypothesis". "Repeated noticing and continued awareness of the language feature is important because it appears to raise the student's consciousness of the structure and to facilitate restructuring of the learner's unconscious system of linguistic knowledge" (p. 272). In other words, when students receive a grammatical point and pay attention to it in practicing exercises or tasks repeatedly, they became aware of and consciously pay attention to that point and this awareness leads to restructuring the unconscious language system or their interlanguage by hypotheses making, testing, and receiving feedback. Through such process declarative/explicit knowledge which was developed by formal instruction leads to the acquisition of that grammatical point and later to procedural knowledge indirectly and over time.

Regarding communication, Ellis (2002) describes that explicit representation of grammatical structure is necessary but not enough for communicating, thus the implicit knowledge is also needed. Consciousness-raising tasks facilitate the learners' ability to communicate and contribute in two major ways to the acquisition of implicit knowledge: 1.through noticing (or the learner's consciousness of the presence of a linguistic feature in input) and comparing linguistic feature with his own mental grammar, consciousness-raising task prepares the grounds for integration of the new linguistic 
material into his mental grammar. This process depends on the learner's developmental readiness. And 2.Consciousness-raising task results in explicit knowledge and helps the learners continue to notice the feature in the input and facilitate the subsequent acquisition.

Ellis (1991) identifies four main characteristics of consciousness-raising task as follows:

- It isolate a specific linguistic feature for focusing attention (it means that the language itself is the content of the task).

- The data that is provided to learners illustrate the targeted feature and it can be inductive which asks learners to construct an explicit rule to describe the grammatical feature that the data illustrate or it can be deductive and give an explicit rule describing or explaining the feature to carry out some task.

- The learners are expected to use intellectual effort to understand the targeted feature (through noticing, comparing, and integrating).

- Learners may be optionally required to verbalize a rule describing the grammatical structure (they may be required to talk meaningfully about a language point using their own linguistic resources) (as cited in Ellis, 2003).

Ellis (2002) postulates that consciousness-raising task approach to grammar emphasizes discovery learning through problem-solving tasks. It means that at first a problem or a source of difficulty is identified and then through deductive or inductive approach a task is created to help the learners promote the explicit knowledge storage. "A consciousness-raising task constitutes a kind of puzzle which when solved enables learners to discover for themselves how a linguistic feature works." (Ellis, 2003, p. 163).

Studies show that consciousness-raising tasks can be effective in developing explicit knowledge, but Ellis (2002) admits this approach has a number of limitations. This approach might not be appropriate for young learners who are not proficient enough to talk about the target feature or those who prefer to learn by doing rather than studying and also for beginners whose first language is used for solving the tasks.

\section{CONCLUSiON}

All in all, it can be concluded that consciousness-raising tasks could be an alternative to traditional grammar teaching in which memorization of specific rules and rule articulation through decontextualized instruction was practiced. By using carefully designed activities and tasks, learners develop explicit knowledge of grammatical aspects which can facilitate the implicit knowledge and the ability to successfully and effectively communicate. As a result, language teachers can use consciousness-raising tasks for pedagogical purposes in their classes whenever they suppose it can be of more privilege.

\section{REFERENCES}

[1] Beglar, D. \& Hunt, A. (2002). Implementing task-based language teaching. In: Richards, J. C. \& Renandya, W. A.. (Eds.). Methodology in language teaching: An anthology of current practice. Cambridge: Cambridge University Press.

[2] Breen, M. P. (1987). Learner contribution to task design. N.J.: Prentice Hall.

[3] Butler, Y. (2005). Comparative perspectives towards communicative activities among elementary school teachers in South Korea, Japan and Taiwan. Language Teaching Research, 9, 423-446.

[4] Bygate, M., Skehan, P., \& Swain, M. (2001). Researching pedagogic tasks: second language learning, teaching and testing. Harlow: Longman.

[5] Candlin, C., \& Murphy, D. (1987). Language learning tasks (Eds.). Englewood Cliffs, N.J.: Prentice Hall International.

[6] Carless, D. (2002). Implementing task-based learning with young learners. ELT Journal, 56, 389-396.

[7] Carless, D. (2004). Issues in teachers' reinterpretation of a task-based innovation in primary schools. TESOL Quarterly, 38, 639-662.

[8] Ellis, R. (2002). Grammar teaching _ Practice or consciousness-raising? In J. C. Richards \& W. A. Renandya (Eds.), Methodology in language teaching: An anthology of current practice (pp. 167174).Cambridge: Cambridge University Press. 
[9] Ellis, R. (2003). Task-based language learning and teaching. Oxford University Press.

[10] Ellis, R. (2009). Task-based language teaching: sorting out the misunderstandings. International Journal of Applied Linguistics, 19 (3), 221-246.

[11] Fotos, S. (1993). Cognitive approaches to grammar instruction. In M. Celce- Murcia (Ed.), Teaching English as a second or foreign language (pp.272-273). London: Heinle \& Heinle, Thomson Learning.

[12] Kumaravadivelu, B. (2006). Learner perception of learning tasks. ITL, 152, 127. doi:10.2143/ITL.152.0.201 7866

[13] Li, D. (1998). It's always more difficult than you planned: teachers' perceived difficulties in introducing the communicative approach in South Korea. TESOL Quarterly, 32, 677-703.

[14] Littlewood, W. (2004).The task-based approach: Some questions and suggestions.ELT journal, 58(4), 319326. doi:10.1093/elt/58.4.319

[15] Long, M., \& Crookes, G. (1991). Three approaches to task-based syllabus design. TESOL Quarterly, 26, 27-56.

[16] Long, M. (1985). A role for instruction in second language acquisition: task-based language teaching. In K. Hyltenstam and M. Pienemann (Eds.), Modelling and assessing second language acquisition. Clevedon: Multilingual Matters.

[17] Murphy, J. (2003). Task-based learning: the interaction between tasks and learners. ELT Journal, 57, 352360.

[18] Nunan, D. (1989). Designing tasks for the communicative classroom. Cambridge: Cambridge University Press.

[19] Nunan, D. (2004). Task-Based Language Teaching. Cambridge: Cambridge University Press.

[20] Nunan, D. (2005). Important tasks of English education: Asia-wide and beyond. Asian EFL Journal, 7,524.

[21] Prabhu, N. S. (1987). Second language pedagogy: A perspective. Oxford: Oxford University Press.

[22] Richards, J. C., Platt, J. \& Weber, H. (1986). Longman Dictionary of Applied Linguistics. London. Harlow, U.K.: Longman Addison-Wesley.

[23] Richards, J. C., \& Renandya, W. A. (2002). Methodology in language teaching: An anthology of current practice. Cambridge: Cambridge University Press.

[24] Richards, J. \& T. Rodgers. (1986). Approaches and Methods in Language Teaching. Cambridge: Cambridge University Press.

[25] Richards, J., \& Rodgers, T. (2001). Approaches and methods in language teaching. Cambridge: Cambridge University Press.

[26] Richards, J., \& Rodgers, T. (2003). Approaches and methods in language teaching. Cambridge: Cambridge University Press.

[27] Richards, J., \& Rodgers, T. (2014). Approaches and methods in language teaching. Cambridge: Cambridge University Press.

[28] Sheen, R. (2003). Focus-on-form: A myth in the making. ELT Journal, 57, 225-233.

[29] Skehan, P. (1998). Task-based instruction. Annual review of applied linguistics, 18, 268-286.

[30] Swan, M. (2005). Legislation by hypothesis: The case of task-based instruction. Applied Linguistics, 26(3), 376-401. doi:10.1093/applin/ami013

[31] Widdowson, H. (2003). Pedagogic design. In defining issues in English language teaching. Oxford: Oxford University Press.

Citation: Maryam Abdollahzadeh. "Task-Based Language Teaching and Implementing ConsciousnessRaising Tasks" International Journal on Studies in English Language and Literature (IJSELL), vol 6, no. 5, 2018, pp. 26-30. doi:http://dx.doi.org/10.20431/2347-3134.0605004.

Copyright: (C) 2018 Authors. This is an open-access article distributed under the terms of the Creative Commons Attribution License, which permits unrestricted use, distribution, and reproduction in any medium, provided the original author and source are credited. 